\title{
Amniotic Fluid Testosterone Concentration as an Index of Fetal Sex
}

\author{
A. KETUPANYA AND W. G. WIEST ${ }^{(16)}$ \\ Department of Obstetrics and Ginecologl, Washington University School of Medicine, St. Louis, Missouri, USA
}

\begin{abstract}
Summary
Testosterone concentrations were measured by radioimmunoassay in 57 amniotic fluid samples obtained from 43 women whose gestational ages varied from $14-40$ weeks. These women were grouped according to the sex of the fetus and the gestational age at the time of amniocentesis: group I, less than 20 weeks; group II, 21-30 weeks; group III, 31-40 weeks. In each gestational age group, mean testosterone concentrations were significantly higher in women bearing male fetuses. Of the 14 patients comprising group I, 8 bore male fetuses. The mean testosterone concentration for male fetuses in this group was $198.7 \mathrm{pg} / \mathrm{ml}$ (range 93-319.8 $\mathrm{pg} / \mathrm{ml}$ ) and $74.1 \mathrm{pg} / \mathrm{ml}$ for female fetuses (range $39-122.8 \mathrm{pg} / \mathrm{ml}$ ). Group II was comprised of 23 patients, 13 of whom bore male fetuses. The mean testosterone concentration for male fetuses was $221.5 \mathrm{pg} / \mathrm{ml}$ (range 133.6-395.0 pg/ml), and for female fetuses it was $67.7 \mathrm{pg} / \mathrm{ml}$ (range 35.6-103.0 pg/ml). Group III consisted of 20 patients of whom 10 bore male fetuses. The mean testosterone concentration for the male fetuses was $149.1 \mathrm{pg} / \mathrm{ml}$ (range $99.2-262.0 \mathrm{pg} / \mathrm{ml}$ ), and for female fetuses it was $60.2 \mathrm{pg} / \mathrm{ml}$ (range $39.5-96.7 \mathrm{pg} / \mathrm{ml}$ ). Some overlapping of individual testosterone values was observed in fluid from male and female fetuses; however, the percentage of women bearing males and having amniotic fluid testosterone concentrations greater than $100 \mathrm{pg} / \mathrm{ml}$ was 93.5\% (29/31). The percentage of women bearing females with testosterone concentrations less than $100 \mathrm{pg} / \mathrm{ml}$ was $88.5 \%(23 /$ 26).
\end{abstract}

\section{Speculation}

Amniotic fluid testosterone concentrations lave proven useful for the antenatal diagnosis of fetal sex. Correlation between the fetal sex based upon testosterone analysis and the amniotic fluid karyotype increases the probability that the cultured cells are of fetal origin. Certainty of diagnosis could be increased even further by combining antenatal sex diagnosis with fluorescent $\mathrm{Y}$-chromatin screening of uncultured amniotic fluid. A combination of these techniques should aid in the elimination of diagnostic errors arising from contamination by maternal cells.

Testosterone is synthesized in the gonads of the male fetus at the time of sexual differentiation and also in small amounts in the adrenal glands of both male and female fetuses $(6,7,9)$. No quantitative differences in adrenal gland synthesis are attributable to the sex of the fetus (6). Testosterone synthesis by fetal testicular tissue from precursor progesterone and pregnenolone has been demonstrated as early as $8-10$ weeks of fetal age (9); the maximum rate of synthesis was observed from tissues obtained between 17-21 weeks of fetal age after which the rate of synthesis expressed per testis declined (9). Testosterone concentration in sera of male fetuses was found to be maximum at 11-17 weeks of gestation (1, 5); thereafter, testosterone concentration declined to a level indistinguishable from that of female fetuses.

Higher testosterone levels measured in maternal plasma compared with levels found in plasma of nonpregnant females are attributable to increased concentrations of testosterone-estradiol binding globulin $(\mathrm{TeBG})(2,3)$, which is capable of specifically binding approximately $97 \%$ of the testosterone circulating during pregnancy (8). Maternal plasma testosterone levels have been shown not to differ significantly according to fetal sex (8). It is expected that amniotic fluid testosterone would be derived from the maternal circulation and from direct contributions of the fetus. Accordingly, significant differences in the magnitude of fetal gonadal testosterone production should be reflected in amniotic fluid levels even though differences are not apparent in the maternal circulation. This expectation has been observed (4).

The present study reports measurements of the testosterone concentration in amniotic fluid at different gestational ages and the correlation of testosterone levels with the sex of the fetus.

\section{MATERIALS AND METHODS}

\section{MATERIALS}

$\left[1,2,6,7-{ }^{3} \mathrm{H}\right]$ Testosterone $(85 \mathrm{Ci} / \mathrm{mmol})$ was purchased from New England Nuclear, Boston, MA. The purity of the labeled steroid was checked periodically by column chromatography on Sephadex LH-20 (Pharmacia Fine Chemicals, Inc., Piscataway, $\mathrm{NJ}$ ). Testosterone, dextran type 5-40, and the Tris-Cl buffer components were purchased from Sigma Chemical Co., St. Louis, MO. Scintiverse is a product of Fisher Scientific Co., St. Louis, MO. All other chemicals and solvents, obtained from common suppliers, were of analytic grade.

\section{PROCEDURE}

Amniotic fluid was withdrawn by standard amniocentesis (11) following placental localization by ultrasonography. Amniocentesis was performed during therapeutic abortion or for the purpose of diagnosing genetic abnormalities, $\mathrm{Rh}$ sensitization, and fetal maturity on 43 patients from whom a total of 57 samples were drawn at gestational ages varying from 14-40 weeks. Amniotic fluid was stored frozen until the time of steroid analysis.

The sex of the infants was determined either from official birth records of fetuses not aborted, from a direct examination of the abortus, or from the karyotyping of cultured amniotic fluid. The gestational age at the time of amniocentesis was determined from the last known menstrual period and confirmed by ultrasonographic measurement of fetal biparietal diameter.

Testosterone concentration was determined by radioimmunoassay using a specific antibody generated in sheep against $11 \alpha$ hydroxytestosterone-hemisuccinyl bovine serum albumin (12). Details of the method applied to human serum have been published (10). A high degree of antibody specificity eliminated the need for preliminary chromatographic isolation of extracted testosterone. Aliquots of amniotic fluid, $2.0 \mathrm{ml}$, made alkaline with $0.2 \mathrm{ml}$ of $0.1 \mathrm{~N} \mathrm{NaOH}$, were extracted with $8 \mathrm{ml}$ benzene-petroleum ether (2:5); these were then taken to dryness and dissolved in $0.1 \mathrm{ml}$ buffer. Recovery of extracted testosterone averaged 86.8 $\pm 8.2 \%(n=29)$. All intervening steps of the assay prior to tritium counting were carried out at ice bath temperature. Steroid extracts 
dissolved in $0.1 \mathrm{ml} 0.05 \mathrm{M}$ Tris buffer, $\mathrm{pH} 8.0$, were equilibrated initially for $1 \mathrm{hr}$ with $0.1 \mathrm{ml}$ antibody-buffer solution (dilution 1:7000) and subsequently for $15 \mathrm{hr}$ after adding $0.1 \mathrm{ml}$ of a solution of $\left[1,2,6,7-{ }^{3} \mathrm{H}\right]$ testosterone $(c a .15,000 \mathrm{cpm})$ in buffer. Unbound steroid was removed during a $20 \mathrm{~min}$ exposure to 0.7 $\mathrm{ml}$ of a suspension of dextran-coated charcoal $(250 \mathrm{mg}$ Norit A. $1.0 \mathrm{~g}$ dextran $/ 100 \mathrm{ml}$ Tris buffer). Charcoal was pelleted by centrifugation $(2000 \mathrm{rpm} \times 20 \mathrm{~min})$, and $0.5 \mathrm{ml}$ of the supernatant solution was mixed with $4.5 \mathrm{ml}$ Scintiverse. Samples were counted with an efficiency of $28.5 \%$. The accuracy of the testosterone assay was established by measurements of known quantities of testosterone added to amniotic fluid. Distilled water usually measured zero eliminating the necessity for a blank correction.

\section{RESULTS}

Evaluations of the accuracy and precision of the testosterone radioimmunoassay applied to the analysis of amniotic fluid are

Table 1. Recovery of testosterone added to pooled amniotic fluid

\begin{tabular}{|c|c|c|c|c|}
\hline \multicolumn{2}{|c|}{ Conc, $\mathrm{pg} / \mathrm{ml}$} & \multicolumn{2}{|c|}{ Recovery } & \multirow{2}{*}{$\begin{array}{c}\text { Coefficient } \\
\text { of varia- } \\
\text { tion, } c_{c}^{c}\end{array}$} \\
\hline Measured' & Added & $\mathrm{pg} / \mathrm{ml}$ & $\because$ & \\
\hline $142.4 \pm 2.6$ & & & & 1.8 \\
\hline $189.3 \pm 5.5$ & 40 & 46.9 & 117 & 2.9 \\
\hline $243.9 \pm 9.4$ & 100 & 101.5 & 102 & 3.9 \\
\hline
\end{tabular}

${ }^{1} \bar{\chi} \pm \mathrm{SD}(n=4) ; \mathrm{Y}=0.91 \mathrm{X}+10.5, r=0.999$.

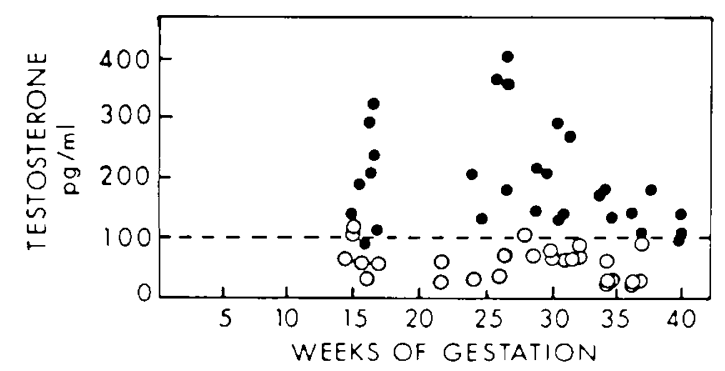

Fig. 1. Amniotic fluid testosterone concentrations determined throughout pregnancy. values obtained from women bearing male fetuses. $O$ : values obtained from women bearing female fetuses.
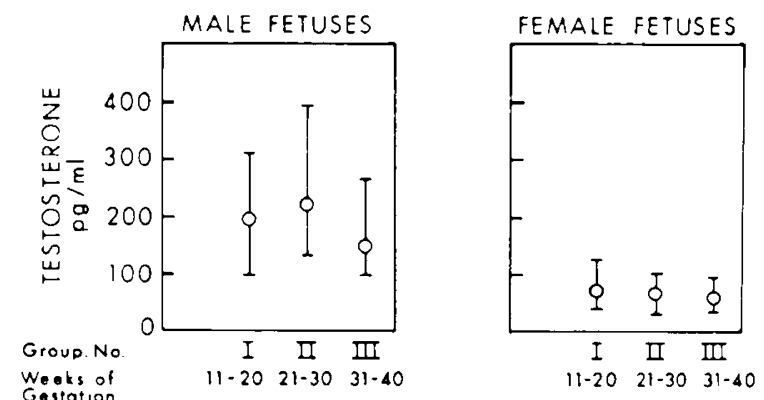

Fig. 2. Amniotic fluid testosterone concentrations in women grouped according to fetal sex and gestational age. Points indicate mean values: extended lines indicate the ranges of the determination within each group. given in Table 1. Figure 1 presents the individual determination of amniotic fluid testosterone according to sex and gestational age. Individual determinations were combined into three groups according to gestational age: group I, 11-20 weeks; group 1I, 21-30 weeks, and group III, 31-40 weeks. The mean testosterone concentrations for each group computed according to fetal sex are given in Figure 2. Of the 14 patients comprising group I, 8 bore male fetuses. The mean testosterone concentration for male fetuses in this group was $198.7 \mathrm{pg} / \mathrm{ml}$ (range $93-319.8 \mathrm{pg} / \mathrm{ml}$ ) and 74.1 $\mathrm{pg} / \mathrm{ml}$ for female fetuses (range $39-122.8 \mathrm{pg} / \mathrm{ml}$ ). Group II was comprised of 23 patients, 13 of whom bore male fetuses. The mean testosterone concentration for male fetuses was $221.5 \mathrm{pg} / \mathrm{ml}$ (range 133.6-395.0 pg/ml), and for female fetuses it was $67.7 \mathrm{pg} /$ $\mathrm{ml}$ (range $35.6-103.0 \mathrm{pg} / \mathrm{ml}$ ). Group III consisted of 20 patients of whom 10 bore male fetuses. The mean testosterone concentration for the male fetuses was $149.1 \mathrm{pg} / \mathrm{ml}$ (range $99.2-262.0 \mathrm{pg} / \mathrm{ml}$ ). and for female fetuses it was $60.2 \mathrm{pg} / \mathrm{ml}$ (range $39.5-96.7 \mathrm{pg} / \mathrm{ml}$ ).

The differences between the sexes within each group were analyzed by Student's $t$-test and found to be statistically significant in all three groups as shown in Table 2. Amniotic fluid testosterone concentrations in women bearing female fetuses were found to be similar in all three groups. However, women bearing male fetuses showed testosterone levels which varied with gestational age, being highest in group II patients (21-30 weeks of gestation), and lowest in group III ( $31-40$ weeks). Statistical differences could not be established between groups I and II males or between groups I and III males, but the difference between groups II and III males was significant $(P<0.025)$.

As shown in Figure 1 the highest testosterone value determined in women bearing females $(122.8 \mathrm{pg} / \mathrm{ml})$ overlapped with the lowest value from those bearing males $(93 \mathrm{pg} / \mathrm{ml})$. However, the percentage of males with values greater than $100 \mathrm{pg} / \mathrm{ml}$ was $93.5 \%$ ( 29 of 31 ), and the percentage of females with values less than 100 $\mathrm{pg} / \mathrm{ml}$ was $88.5 \%$ (23 of 26 ). Similar comparisons made within each of the three groups showed overlapping values between males and females in group I having gestational ages of 20 weeks or less, but no overlap within groups II or III. Patients in group II who bore male fetuses had the highest values observed which tended to reduce the likelihood of overlap with the female range. Thus, determination of amniotic fluid testosterone levels between 20 and 30 weeks of gestation should provide the most discriminating evaluation for the rapid antenatal diagnosis of fetal sex.

\section{DISCUSSION}

Antenatal determination of fetal sex for the purpose of anticipating sex-linked disorders has proved helpful for genetic counseling with families known to be carriers. Although the diagnostic accuracy of amniotic fluid chromosome analysis is high. it is disturbing to note that misdiagnoses do occur from time to time. One of the potential sources of error is contamination of the amniotic fluid with maternal cells. Several techniques have been developed to minimize this possibility. These include in situ processing of cultured amniotic fluid cells, fluorescent $Y$-chromatin screening of uncultured samples and Q-polymorphism comparisons between mitoses from the amniotic fluid cells and maternal lymphocytes. Each of these techniques has its own drawbacks and diagnostic limitations.

Table 2. Amniotic fluid testosterone concentrations

\begin{tabular}{|c|c|c|c|c|c|c|}
\hline & \multicolumn{2}{|c|}{ Group I, $<20$ weeks of gestation } & \multicolumn{2}{|c|}{ Group II, 21-30 weeks of gestation } & \multicolumn{2}{|c|}{ Group III, 31-40 weeks of gestation } \\
\hline & Male fetuses & Female fetuses & Male fetuses & Female fetuses & Male fetuses & Female fetuses \\
\hline Testosterone conc. $\mathrm{pg} / \mathrm{ml}$ & 199 & 75 & 222 & 68 & 149 & 60 \\
\hline SD & 82 & 32 & 97 & 23 & 48 & 21 \\
\hline Range & $93-320$ & $39-123$ & $134-395$ & $36-103$ & $99-262$ & $40-97$ \\
\hline No. of samples & 8 & 6 & 13 & 10 & 10 & 10 \\
\hline$t$ value & \multirow{2}{*}{\multicolumn{2}{|c|}{$\begin{array}{l}3.5 \\
<0.005\end{array}$}} & \multirow{2}{*}{\multicolumn{2}{|c|}{$\begin{array}{c}4.91 \\
<0.001\end{array}$}} & \multicolumn{2}{|c|}{5.40} \\
\hline$P$ & & & & & & \\
\hline
\end{tabular}


The testosterone concentration of amniotic fluid can be rapidly and economically established with only a few milliliters of supernatant fluid. Correlation of the fetal sex based upon this test with the amniotic fluid karyotype could serve to further increase confidence that the analyzed cells are indeed of fetal origin. The certainty of diagnosis could be even further increased by combining the testosterone evaluation with fluorescent Y-chromatin screening of the uncultured fluid. A combination of such techniques should eliminate the possibility of diagnostic error because of maternal cell contamination.

\section{CONCLUSION}

A radioimmunoassay is presented which is suitable for determining the testosterone concentration of amniotic fluid. Assay of fluid drawn from 43 women between the 14th and 40th weeks of pregnancy demonstrated a significantly higher steroid level in fluid from women bearing male fetuses. The greatest margin of difference between male- and female-bearing women was evident between 20 and 30 weeks of gestation. This difference provides a discriminating evaluation for the rapid antenatal diagnosis of fetal sex with a low probability of error.

\section{REFERENCES AND NOTES}

1. Abramovich, D. R., and Rowe, P.: Foetal plasma testosterone levels at midpregnancy and at term: Relationship to foetal sex. J. Endocrinol., 56: 621 (1973).

2. Forest, M. G., Ances, I. G., Tapper, A. J., and Migeon, C. J.: Percentage of binding of testosterone, androstenedione and dehydroisoandrosterone in plasma at the time of delivery. J. Clin. Endocrinol., 28: 34 (1968).
3. Gandy, H. M.: Androgens, In: F. Fuchs, and A. Klopper: Endocrinology Pregnancy, p. 101 (Harper \& Row. New York. 1971).

4. Giles, H. R., and C. D. Christian: Intrauterine fetal sex determination radioimmunoassay of amniotic fluid testosterone, Gynecol. Invest.. S: (1974).

5. Reyes, F. I., Boroditsky, R. S., Winter, J. S. D., and Faiman, C.: Studies human sexual development. II. Fetal and maternal serum gonadotropin a sex steroid concentrations. J. Clin. Endocrinol. Metab., 38: 612 (1974).

6. Reyes, F. I., Winter, J. S. D., and Faiman, C.: Studies on human sexu development. I. Fetal gonadal and adrenal sex steroids. J. Clin. Endocrin Metab., 37: 74 (1973).

7. Rice, B. F., Johanson, C. A., and Sternberg, W. H.: Formation of stero hormones from acetate $-1{ }^{14} \mathrm{C}$ by a human fetal testis preparation grown organ culture. Steroids, 7: 79 (1966).

8. Rivarola, M. A., Forest, M. G., and Migeon, C. J.: Testosterone, androstenedion and dehydroepiandrosterone in plasma during pregnancy and at deliver Concentration and protein binding. J. Clin. Endocrinol., 28: 34 (1968).

9. Siiteri, P. K., and Wilson, J. D.: Testosterone formation and metabolism duri male sexual differentiation in the human embryo, J. Clin. Endocrinol. Metal 38: 113 (1974)

10. Wiest, W. G.. Paulson, J. D., Keller, D. W., and Warren, J. C.: Free testosteror concentration in serum: A method for determination. Amer. J. Obstet. Gyn col. (In press).

11. At the time of amniocentesis the purpose and nature of the study was careful explained to each patient, and all gave their fully informed consent.

12. Antiserum S-250 was a gift from Dr. Gordon D. Niswender, Colorado Sta University, Fort Collins, Colorado.

13. We express appreciation for the excellent technical assistance of Mrs. Le Paloheimo in the testosterone radioimmunoassay, and to Dr. James P. Crar for helpful suggestions made during preparation of the manuscript.

14. The present address of Dr. A. Ketupanya is: $113 / 3$ Soi Chitrom, Twanon Roa Bangkok 19. Thailand.

15. This research was supported in part by Grant T01-HD 00379 from the NICHHI 16. Requests for reprints should be addressed to: Dr. Walter G. Wiest. Dept. Ot Gyn., Washington University School of Medicine, 4911 Barnes Hospital Plaz St. Louis, MO 63110 (USA)

17. Received for publication June 29, 1977

18. Accepted for publication August 29, 1977. 